\title{
THE EFFECT OF APPLIED BEHAVIOR ANALYSIS ON THE DEVELOPMENT OF AUTISTIC CHILDREN
}

\author{
Atik Badi'ah'), Heru Santosa Wahito Nugroho's), Ni Ketut Mendri') \\ 1)Study Program in Nursing, School of Health Polytechnics, \\ Ministry of Health Yogyakarta \\ ${ }^{2)}$ School of Health Polytechnics, Ministry of Health Surabaya
}

\begin{abstract}
Background: Autism is a developmental disorder characterized by difficulties with social interaction and communication, and by restricted and repetitive behavior. Applied Behavior Analysis (ABA) is an approach to understanding and changing behavior. It's not a specific therapy itself, but a range of different strategies and techniques that can be used to teach people with autism spectrum disorder new skills and reduce their difficult behavior. This study aimed to determine the effect of applied behavior analysis on the development of autistic children at autism school.

Subjects and Method: This was a randomized controlled trial. This study was conducted at 7 autism schools in Yogyakarta province (Fajar Nugraha, Samara Bunda, Bina Anggita, Dian Amanah, Trustees, Citra Mulia Mandiri, and Autism Service Center) and 1 Baitul Qur'ani autism school in Ponorogo, East Java. A total of 92 autistic children aged 6-12 years was selected for this study and randomized into two groups: ABA group and control group. The dependent variable was development. The independent variable was ABA. The data on child development was measured by Screening Tool for Autism in Toddlers and Young Children (STAT). The data were analyzed by t-test.

Results: Before the intervention, the means of STAT score between the two study groups were comparable. As a result of randomization, the mean difference of STAT scores between the two groups was statistically non-significant. After the intervention, mean of STAT scores was higher in the ABA group than in the control group, and it was statistically significant.
\end{abstract}

Conclusion: Applied Behavior Analysis is effective in improving the development of autistic children.

Keywords: Applied Behavior Analysis, development, autistic children

\section{Correspondence:}

Atik Badi'ah. Study Program in Nursing, School of Health Polytechnics, Ministry of Health Yogyakarta, Indonesia. Email: atik.cahyo@yahoo.com. Mobile: 08164267407. 